\title{
映画『Fukushima 50』をどう受けとめるか
}

$$
\text { フリージャーナリスト＼cjkstart井内 千穂 }
$$

新型コロナ禍中， 3 月上旬の封切り直後の週末にこの映画を観に行った。事故発生当時は知る由もな かった現場の凄まじさを追体験する映像と人々の命懸けの奮闘に心を摇さぶられる作品だった。

感動のヒューマンドラマであって事実の記録ではないのか？ 案の定，映画に関する賛否両論の感想 がネット上に溢れている。同じ映画に対して，事故の強烈な映像が反原発感情を増幅させるという䯚念 と，逆に，現場のヒロイズムが政権のプロパガンダになるという少念の両方がある。元々の立場によっ て受けとめ方は異なるが，何かしら摇さぶられての反応か。しかし，「事実」とは何だろう。

劇中,「俺たちは何が間違ってたんだろうな」と問う伊崎当直長(佐藤浩市)から吉田所長(渡辺謙)への 言葉が重く残る。「自然を侮った」とは，津波対策を先送りしたことなのか，福島に原発を建てたことな のか，そもそも原子力という技術自体を言うのか？ 事実はともあれ，映画は問うている。

どんなに安全対策を講じてもゼロリスクはない。そして, 原発を止めても別のリスクがある。実際, 現下の危機はこのコロナ禍である。世界中の現場で，医療関倸者の奮闘はもちろん，自分を含めた一般 市民も必死の努力を続けている。国境は閉ざされたが，玉石混交の情報が世界を駆け巡る。

いろいろ読み過ぎた感想を検証するため，もう一度映画を観ようと思っているうちにコロナ禍はさら に深刻化し映画館もクローズしてしまった。自宅に引きこもったまま，気になる「事実」に近づく手立て

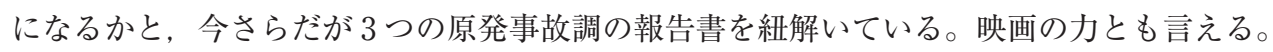

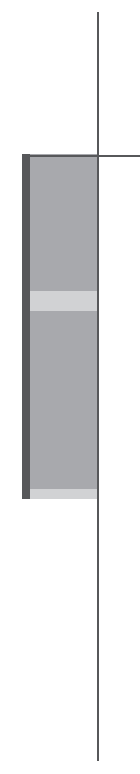

\section{Column}

\section{環境問題にとっての「未来」とは}

\section{東京学芸大学附属国際中等教育学校 3 年 小澤 杏子}

「未来」とは，一体いつのことを指しているのか。地球の未来のために，私たちの未来のために環境問 題を解決していこう ... などといったフレーズに使われている「未来」は, 一体いつ訪れるのであろうか。 私は，「未来」という言葉がいいように使われ，この言葉を使うことで環境問題解決の見えない期日を先 延ばしにしているのではないかと思ってしまう。

人類の歴史上，環境問題が多く取り上げられるようになったのはつい最近のことである。産業革命後 の科学技術の著しい進歩により，今までは自然が相殺できていた環境破壊に歯止めが効かなくなってし まったのである。世界的に見ると，環境に配慮した国の政策や人々の活動が以前より増えた気がする。 しかし，日本はどうだろうか。

昨年の 12 月 3 日，国際的な NGO である「気候行動ネットワーク」は COP25(気候变動枠組条約第 25 回締約国会議)の会場で, 地球温暖化対策に消極的な国に贈る, 不名誉な「化石賞」に日本などを選出した ことを発表した。な押，資源エネルギー庁などの調査結果によると，2018 年の発電電力量のおよそ 8 割 が火力発電で賄われている。

国内外のさまざまな企業や団体が環境問題と向き合っているというのに，国全体としては積極的に環 境保全に繋がるような取り組みが行えていないように見えてしまう。土地面積もなく，資源大国でもな い日本にとってエネルギー関連の課題解決は困難なことなのかもしれない。しかし，「未来」をより良く するためには困難な課題と向き合い, 直ちに解決していくのが必要不可欠だと思う。 